\title{
Ricardo flies Ryanair: Strategic human resource management and competitive advantage in a Single European Aviation Market
}

\author{
Geraint Harvey $^{1} \odot$ | Peter Turnbull ${ }^{2}$
}

\author{
${ }^{1}$ Centre for People and Organisation, School \\ of Management, Swansea University, Bay \\ Campus, Swansea, UK \\ ${ }^{2}$ School of Management, University of Bristol, \\ Bristol, UK
}

\section{Correspondence}

Peter Turnbull, School of Management, University of Bristol, Howard House (3.10), Queens Ave, Bristol BS8 1SN, UK. Email: peter.turnbull@bristol.ac.uk

\section{Funding information}

European Transport Workers' Federation and European Commission (DG Employment), Grant/Award Number: VS/2011/0182 and VS/2013/0184

\begin{abstract}
How and why are some firms, such as Ryanair, able to consistently record industry-leading profitability that sustains a competitive advantage over their rivals? Human resource management (HRM) plays a critical role in four widely recognised profit-generating mechanisms, albeit not always in ways predicted by mainstream strategic HRM. Studies of HRM $\rightarrow$ performance grounded in the resourcebased view of the firm invariably focus on the human resources already controlled by the firm-specifically, resources that are rare, inimitable, non-substitutable and can be exploited through organisation-rather than strategic factor markets where firms acquire their human resources. In doing so, these studies overlook the industrial relations and wider institutional context that might variously promote, permit or preclude particular HR policies and practices. It is only when different profit-generating mechanisms, either in isolation or combination, are activated under the auspicious conditions of a particular time and place that HRM contributes to sustained competitive advantage.
\end{abstract}

\footnotetext{
Abbreviations: CEO, Chief executive officer; EC, European Commission; ECA, European Cockpit Association; ECJ, European Court of Justice; ERCs, Employee Representative Committees; ETF, European Transport Workers' Federation; EU, European Union; FG, focus group; LFAs, low-fare airlines; OECD, Organisation for Economic Co-operation and Development; RBV, resource-based view; RINO, rare, inimitable, non-substitutable and exploitable through organisation; RPG, Ryanair Pilots' Group; SEAM, Single European Aviation Market; SFMs, strategic factor markets.
}

This is an open access article under the terms of the Creative Commons Attribution License, which permits use, distribution and reproduction in any medium, provided the original work is properly cited.

(c) 2020 The Authors. Human Resource Management Journal published by John Wiley \& Sons Ltd. 
KEYWORDS

competitive advantage, economic rent, industrial relations, RBV, strategic factor markets, strategic HRM

\section{Practitioner notes}

What is currently known about the subject matter?

1. Strategic human resource management (HRM) and the resource-based view typically focus on firms' internal resources

2. External strategic factor (labour) markets are typically discounted as a source of competitive advantage

3. The legal and cultural context of the firm influences the choice of business and HRM strategy

\section{What their paper adds to this?}

1. Demonstrates how firms earn economic rents from external strategic factor markets (SFMs)

2. Reconnects HRM with the field of industrial relations

3. Demonstrates the importance of a qualitative process approach to the study of HRM

\section{The implications of study findings for practitioners}

1. SFMs are an important source of competitive advantage

2. HR policies and their outcomes are influenced by, and also influence, the broader industrial relations context

3. External actors often take action that nullifies competitive advantage secured through particular HR policies

\section{1 | INTRODUCTION}

In order to explain whether, when and most importantly how and why human resource management (HRM) creates high(er) performance, we need to look outside as well as inside the firm. Too much research in the field of strategic HRM in particular ignores the impact of context, or at best attempts to 'control away context' (Johns, 2017, p. 577), resulting in 'a (mostly) closed system' (Kaufman, 2015, p. 112). When the system is 'opened up', HRM phenomena are found to be context-dependent and interdependent, as demonstrated most readily in the case of multinational companies (Cooke, 2018). Consider the case of Ryanair, an Irish-owned airline operating from more than 80 bases across Europe. In the context of a Single European Aviation Market (SEAM), all airlines registered in the European Union (EU) enjoy equal access to a single (product) market. However, they experience distinctly unequal access to different labour markets. Every EU member state has its own distinct employment laws, trade union recognition and organisation, collective bargaining arrangements, dispute resolution procedures and other institutional features of the industrial relations system. These different systems condition the cost, compliance and contribution of labour to the firm's business strategy and profitability. It is lamentable, to say the least, that the field of strategic HRM has only 'become successful by developing a narrow [closed] focus on economic performance', divorcing itself from cognate fields such as industrial relations 'with which it should be closely connected' (Beer, Boselie, \& Brewster, 2015, p. 428).

It is high time for the theory of strategic HRM to be reconnected with industrial relations and the (institutional) analysis of the wider political economy. Ironically, the resource-based view (RBV) of the firm-'the guiding paradigm 
on which virtually all strategic HRM research is based' (Allen \& Wright, 2007, p. 9)-offers a framework to achieve precisely this. Decontextualized studies of HRM $\rightarrow$ performance invariably focus on the internal (human) resources of the firm that are rare, inimitable, non-substitutable and exploitable through organisation (RINO). For the RBV, context is potentially 'captured' in strategic factor markets (SFMs) where firms acquire the resources they need to implement their product market strategies, in particular the SFM for labour. However, as these markets are assumed to be 'perfectly competitive', ipso facto, they cannot be the source of competitive advantage (Barney \& Clark, 2007, pp. 16-17). But what if firms' access to different labour markets is imperfect? Dropping the fallacious assumption of perfectly competitive SFMs is evidently the most effective way to reconnect (strategic) HRM and industrial relations.

Once it is acknowledged that the context of industrial relations varies over both time and place, political opportunities open up for some firms to 'create or exploit competitive imperfections in SFMs' (Barney, 1986, p. 1232, emphasis added), earning higher than normal returns in the form of an economic (Ricardian) rent. The following section demonstrates how some firms are indeed able to create and exploit competitive imperfections in SFMs via four different (interactive) profit-generating mechanisms, namely rivalry restraint, information asymmetry, competitive advantage and commitment timing (Makadok, 2011). For each profit-generating mechanism, the industrial relations context can either promote, permit or preclude particular HR policies and practices. Most notably, in a single European market with free movement of capital, labour, goods and services, a worker from country $A$ might be hired via an agency in country B, under the employment laws of country C, but actually work in country D. Multinational firms are then able to exploit the 'spaces of exception' in this particular (European) context, 'mov[ing] across national boundaries, carrying with them home country practices and regulatory frameworks, protected by enclaves of alternative sovereignty, unregulated by local authorities and trade unions' (Lillie, 2010, p. 695). Workers then find themselves in a state of 'liminality', a particular kind of being 'betwixt and between' the positions assigned and arrayed by law, custom and convention, which is increasingly commonplace within the ranks of precarious workers on 'atypical' contracts. In extremis, these workers are 'neo-villeins' who are not only insecure but actually engage in unpaid work for the firm (Harvey, Rhodes, Vachhani, \& Williams, 2017).

In any context, when a firm secures an economic rent via underutilised resources, this represents genuine value creation and is therefore 'pro-social'. If, in contrast, it is achieved by paying a below-competitive price to a resource owner who is constrained by lack of alternatives, then such 'rent-seeking' behaviour or 'rent capture' (Kaufman, 2015, p. 531) is akin to 'social dumping'. The latter involves 'the circumvention of existing European and national legislation (including ... applicable collective agreements), which enable the development of unfair competition ... and lead to violations of workers' rights and exploitation of workers. ${ }^{1}$ As such, this is not only a contravention of the European Pillar of Social Rights (EC, 2017) but a far cry from the high commitment bundles of HR 'best practices' that feature prominently in strategic HRM. Nonetheless, when profitability is 'the only metric in a capitalist economy for measuring "high performance" ... [this] could equally well be the sweatshop model' (Kaufman, 2010, p. 97).

The most profitable airline in the world, over many years, is Ryanair, the Irish low-cost carrier that now 'covers all of Europe', in the words of its own CEO, 'a bit like a social disease'. ${ }^{2}$ In presenting a qualitative (Iongitudinal) case study of Ryanair in a subsequent section, our aim is twofold. First, to identify the sources and appropriation of economic rent from SFMs, thereby reconnecting industrial relations and strategic HRM and deepening our theoretical understanding of HRM $\rightarrow$ performance. Second, to assess the (un)sustainability of Ryanair's ultra-low-cost model, given that organised labour and the (social democratic) state will sooner or later demand their share of any economic (Ricardian) rents.

\section{2 | GENERATING ECONOMIC RENT IN THE SKIES OVER EUROPE}

How do airlines make a profit? The simple answer is 'they don't' (Button, 2012, pp. 201-202). Globally, the airline industry returned a cumulative operating profit of US\$44bn between 1999 and 2008, translating into a margin of just over $1 \%$. In aggregate, therefore, in what is now a highly competitive (open) market, airlines appear to earn no 
more than 'normal profit' (i.e., sufficient revenue to cover total costs and sustain competitive parity). The world's three leading low-fare airlines (LFAs), however, delivered US\$11.5bn in operating profit between 1999 and 2008, with Ryanair leading the field with a margin of almost $19 \%$ followed by Southwest Airlines (just under 9\%) and easyJet (6\%; Tarry, 2010). Ryanair's profits after tax were less than $€ 500 \mathrm{~m}$ in 2008 but tripled to $€ 1.45 \mathrm{bn}$ a decade later. As any practitioner will tell you, much of what really counts in business is to be found in the 'high performing' tail of the distribution, with the exceptional rather than the commonplace: the outlier rather than the average.

Following the RBV, sustained competitive advantage is demonstrated by the firm's ability to create and conserve economic rent, 'defined as returns to a factor in excess of opportunity cost' (Barney \& Clark, 2007, p. 28). Ricardo's (1817) theory of rent, as codified in the RBV of the firm (Barney \& Clark, 2007, pp. 8-11), is based on land ownership (inelastic supply) and natural differences in the productiveness (fertility) of land brought into cultivation as demand increased. Market price is determined by the least productive land brought into cultivation, giving the owner of more fertile land with lower costs a surplus or economic rent. According to Ricardo, and subsequently Marx, the surplus (economic rent) was 'captured' (fully appropriated) by the landlord, as the peasants who worked the land could not withhold any surplus (otherwise s/he would be replaced by landless peasants). Their 'subsistence wage' included 'transfer earnings', such that the wage was sufficient to dissuade the peasant from seeking alternative employment on some other rental land. Most (contemporary) landlords (employers) do not have complete power of appropriation and must therefore 'share' the surplus with their peasants (workers) according to the bargaining power of each party and the contract between them. Thus, in modern-day parlance, in order to secure the services of labour, the employer must pay something more than the 'opportunity cost' (i.e., the worker's 'transfer earnings'), especially when trade unions negotiate a share of the rent for their members. But what constitutes a 'fair share', especially in the absence of a trade union? What if the employer enjoys buyer power (monopsony) in its SFMs?

Under the RBV, the firm can only create competitive imperfections in SFMs by exploiting its RINO capabilities in these markets in order to generate more accurate expectations about the future value of resources, that is, by 'combin[ing] resources and capabilities it already controls with those that it seeks to acquire in a SFMs' (Barney, 1986; Barney \& Mackey, 2016, p. 373). At Southwest Airlines, for example, company pilots interview prospective pilots as part of the selection process to help the company to identify candidates whose values and personal attributes are most closely aligned to the 'Southwest Way'. This is just one illustration of why 'it is not possible to apply one [RINO] without the other [SFM]' within the RBV (Barney \& Mackey, 2016, p. 373; Kaufman, 2015), but strategic HRM still gravitates towards the one rather than the other, invariably overlooking any interaction between the two. More importantly, any economic rents from the interaction between RINO and SFMs are attributable to expectations rather than exploitation (appropriation of the surplus).

If profits are the result of expectations rather than exploitation, then high performance can be attributed, in part, to human agency in dealing with uncertainty, designated 'entrepreneurial rent' (Chadwick \& Dabu, 2009, p. 254). While it might be tempting to attribute Ryanair's superior profit margin to exceptional foresight at times of great uncertainty (e.g., securing a massive discount on Boeing aircraft ordered in the immediate aftermath of 9/11 and then again during the global financial crisis), this is more likely to produce a temporary rather than a sustained competitive advantage. More important is the introduction of new products or services that 'jolt' the market from its existing order via the (re)configuration of resources to exploit new or existing market opportunities. The low-cost operational model pioneered by Southwest Airlines in the United States created a new service offer combining lower fares with a more basic (commodified) flying experience. Thus, whereas traditional Ricardian rent mechanics explain earnings in excess of normal profit when output is homogeneous and input costs are heterogeneous across firms, managerial entrepreneurship helps to explain monopolistic competition profit resulting from heterogeneous outputs, that is, the firm 'sells you something different' that rivals cannot or will not offer.

Over time, of course, rivals can and may well be forced to likewise 'sell you something different'. To be sure, rivalry restraint (avoiding competition) can be sustained under a cartel or in a highly regulated industry where the number of market participants is strictly limited (e.g., a bilateral air service agreement between two sovereign 
states that only allows national 'flag' airlines to operate designated routes). However, once the market is opened to new competitors with a different (lower cost) business model, then 'if you can't beat them, join them' (Makadok, 2011, pp. 1318-1319). After all, there is nothing inherently inimitable about online booking, high(er) seat density (less leg room), flying a single type of aircraft, reducing aircraft turnaround time at airports and many of the other innovations associated with the low-cost operating model (Alamdari \& Fagan, 2005). In the SEAM, some LFAs such as easyJet compete head-on with the traditional (legacy) airlines by offering passengers 'low costs with care and convenience', flying to more primary airports across Europe than any other airline. Ryanair, in contrast, 'refuses to fall for any of this old management bullshit, or MBA rubbish about clichéd concerns for passengers' (Michael O'Leary, CEO of Ryanair, quoted by Kilduff, 2010, p. 9), offering instead the most basic service on 'alternative routes' to secondary airports typically located some distance from major conurbations. In this context, there is evidently a rather different profit-generating mechanism at work, which raises the question of how Ryanair generates traditional Ricardian rents by flying to secondary airports?

Economic rent from land (airports) is the value of the difference in productivity between a given piece of land and the poorest and/or most distant piece of land producing the same good (landing slots for aircraft) under the same conditions (of labour, capital, technology, etc.), given that the closer a piece of land is to the urban core the higher will be its market rent (reflecting economic rent). Following Ricardian rent theory, which explains the economic return that (agricultural) land should accrue for its use in production (cultivation), the usual assumption is that the original land (primary airports) produced enough food (landing slots, ground handling services, etc.) to feed the population (passengers). The theory then predicts that as the population (travelling public) grows, new land (secondary airports) is brought into cultivation (service), creating economic rent at the original land (primary airports). This assumes, of course, that secondary airports serve the same passengers (grow the same crops). Despite a much lower value passenger base, Ryanair is still able to generate economic rent because while output is homogeneous (low-cost flights), input costs are heterogeneous, that is, the airline's marginal costs are much lower than other LFAs, principally as a result of much higher labour productivity (fewer aircrew dealing with more passengers) and much lower labour costs (wages, benefits and social payments/taxation).

Ryanair is driven by a constant search for new markets, opening more routes every year than any other European airline and downsizing (reducing flight frequencies) and abandoning more routes and airports than any other carrier (Malighetti, Paleari, \& Redondi, 2016, p. 234, 238). The airline's constantly expanding and reconfigured route network, with new bases opening/closing every year, is an important element of an information asymmetry between the airline and its aircrew. When one party (airline) to an economic transaction possesses greater material knowledge than the other party (aircrew), then 'you can fool some of the people some of the time' (Makadok, 2011, p. 1319).

For workers, locations that are 'uniquely attractive' can increase employer-switching costs and thereby enable the firm to retain valuable human resources and generate non-traditional Ricardian rent from RINO (Chadwick \& Dabu, 2009, p. 259). But what if workers are promised the 'high life ... a job that gives you wings', ${ }^{3}$ only to find themselves assigned to a remote base where they are required to live within 1-h travel time of the (secondary) airport? This uniquely unattractive proposition is an example of 'adverse selection' where the employer has more information (ex ante) than the employee prior to the parties agreeing to the contract. 'Moral hazard', in contrast, involves the employer influencing the value of the transaction post hoc. In other words, initial terms and conditions are well known to the new recruit, but future remuneration, shift-arrangements, annual leave, promotion, base assignment and so on, may not live up to 'reasonable expectations' based on professional standards, industry practice and the like. Either way, the airline is able to operate low-cost flights from bases that many aircrew regard as unattractive.

Whereas rivalry restraint and information asymmetry are about how to avoid competition, competitive advantage-to the victor go the spoils' (Makadok, 2011, p. 1318)-is about how to beat the competition by transforming inputs into outputs in a way that outcomes cannot be matched or HR processes imitated by rivals. This is the primary focus of strategic HRM and countless quantitative studies of HRM $\rightarrow$ performance. Under the RBV, human assets represent a special form of strategic asset, not simply human capital with the potential to generate economic 
rent but also agents (antagonists) who might (re)claim some of this rent from the owners and managers of capital. After all, Ricardo described profits as the 'leavings of wages'. In this context, as we demonstrate in the case study that follows, it is only by reconnecting industrial relations and strategic HRM that it is possible to explain how SFMs and RINO interact to enable firms to generate and appropriate traditional and non-traditional Ricardian rents.

As a new start-up, the low-cost airline is in a vulnerable position. Most in fact fail or are bought-out by their more successful rivals (Button, 2012, pp. 208-209). Nonetheless, incumbent firms (e.g., legacy airlines such as British Airways) with all the necessary resources and capabilities to serve a new potential market (e.g., low-cost flights for passengers 'visiting friends and relatives' or weekend stag/hen parties) may either fail to recognise this potential or fear it might damage the firm's brand image. In this context, an upstart challenger with inferior resources and capabilities but superior managerial entrepreneurship may recognise the market potential and therefore pioneer new services in a pre-emptive way in order to capture traditional Ricardian rents (Makadok, 2011, p. 1329). For example, easyJet started UK domestic flights with just two aircraft wet leased from GB Airways, which at the time operated under a franchise agreement with British Airways. The ability to transform inputs into outputs (competitive advantage) will therefore play a key role in commitment timing-that is, when, where and how to invest or innovate-as 'the early bird gets the worm, but the second mouse gets the cheese' (ibid, p. 1320). Optimum timing is always a trade-off between pre-emption (early commitment generates advantages vis-à-vis rivals) and flexibility (delayed commitment can provide advantages in adjusting to environmental forces).

Ryanair was certainly a 'first-mover' (early bird) among LFAs in Europe, learning its trade on more open Ireland-UK routes in the early 1990s prior to the gradual creation of a SEAM with full cabotage by 1997. Ryanair adheres more closely to the operational elements of the low-cost model than any other airline (Alamdari \& Fagan, 2005), which creates a $30 \%-50 \%$ cost advantage over legacy airlines on intra-European routes. Ryanair's total cost advantage, however, is closer to $60 \%$, principally as a result of high(er) labour productivity and much lower labour costs for aircrew (Harvey \& Turnbull, 2012, pp. 14-15).

In developing its industrial relations and HRM strategy, Ryanair was able to adopt a more 'flexible' (second mouse) approach. In the United States, Southwest Airlines entered a highly unionised aviation market in the early 1970s where rivalry between airlines was 'restrained' by the Civil Aeronautics Board (abolished in 1978). This context set the airline along the (dependent) path to industrial relations and HRM 'best practices' that clearly resonate with economic theories of rent-sharing, on the one hand, and competitive advantage derived from resources that deliver on RINO, on the other (Barney \& Clark, 2007, pp. 126-127). In contrast, Ryanair was in a position, first, to know how to emulate Southwest's low-cost operating model. Secondly, Ryanair was then able to appropriate far more of the available rent by pursuing an aggressive anti-union policy (Harvey \& Turnbull, 2015; O'Sullivan \& Gunnigle, 2009) that 'exports' home country industrial relations and HR practices via the 'spaces of exception' in the SEAM (i.e., a single product market with 28 different SFMs for labour, each one set in its own particular industrial relations context). For Ryanair, the SEAM represents an 'institutional space of opportunity that can be strategically exploited to sustain seemingly illegitimate practices' (Crane, 2013, p. 63) such as hiring pilots through an intermediary on (bogus) 'self-employment' contracts (Ricardo-AEA, 2019, chap. ix).

\section{3 | RESEARCHING RENT-SEEKING}

A realist view of causal (relational) processes recognises that the outcome(s) of different profit-generating mechanisms cannot be determined a priori, because mechanisms interact with the context in which they operate. We therefore need to ask: what are the contextual conditions for a particular causal mechanism to take effect and produce the observed empirical outcome(s)? To address this question, a longitudinal (process) study is preferred over a cross-sectional (variance) study, especially as the RBV seeks to explain sustained competitive advantage. Simply put, this is the difference between: 'do A and then $B$, in the context of $C$, to get $Z$ ' (process) versus 'more $X$ and more $\mathrm{Y}$, holding $\mathrm{C}$ constant, produces more $\mathrm{Z}$ ' (variance). 
To understand how causal mechanisms are (de)activated by context, researchers are encouraged to 'plunge deeply' into the analysis of fine-grained, real-time data collected over time (Langley, 1999, pp. 691-692). Such data are invariably 'messy', but a qualitative process approach is designed 'precisely to take into account the context' (ibid, p. 692). To make sense of the data, the narrative of events over time helps us to understand the meaning ascribed to different events by different actors (e.g., changes to the contractual status of aircrew), especially when we challenge the accounts, assumptions and causal attributions of social actors. Temporal patterns in the data can be identified via mapping (e.g., the airline's expanding route network and location of operational bases) and quantification (e.g., the number and proportion of permanent versus agency aircrew, profits and passenger numbers and any variation between high/summer and low/winter seasons). The (de)activation of causal mechanisms can then be explored through temporal bracketing (e.g., changes wrought by legal cases heard by national and European courts on applicable employment law) and most importantly alternative templates (comparing interpretations of the same events based on different a priori theoretical premises; cf. Cooke, 2018). This retroductive mode of inferencefrom the concrete ('what is going on here'?) to the abstract ('what is this a case of'?) and back again-is essential to uncovering the causal (profit-generating) mechanisms at work in any given time, place and organisational setting (Vincent \& Wapshott, 2014).

Analysis of the competitive advantage of leading firms such as Ryanair clearly requires company and workplace data (cf. Makadok, 2011, p. 1331), but the case study is not simply 'the firm' when undertaking a longitudinal study as data are collected on a multitude of events, activities and social interactions. In particular, by virtue of the business model in question, (i.e., aircrew of multiple European nationalities, flying an Irish-registered aircraft, under Irish employment law, but working from a base outside the Republic of Ireland) our case is comparative over time and place, with data collected from a variety of sites and moments in time. The data include the following:

1. Secondary sources such as company reports and industry magazines, trade union sponsored research (e.g., Jorens, Gillis, Valcke, \& De Coninck, 2015), reports from specialist aviation research centres and reports for the European Commission (e.g., Ricardo-AEA, 2019), legal cases brought by aircrew against Ryanair, and online discussion groups used by aviation workers (e.g., www.pprune.org)

2. Two studies with the European Transport Workers' Federation (ETF) on the impact of low-cost competition, incorporating case studies of five leading LFAs and a questionnaire survey of European aircrew (Harvey \& Turnbull, 2012, 2014)

3. More than 60 semi-structured interviews with national and international trade union officials, shop stewards and airline managers (reported as Interview data)

4. Five focus group discussions with Ryanair pilots held in Dublin (reported as FG data)

5. Attendance at numerous union organising meetings with pilots and cabin crew at various locations across Europe

6. Survey data on the working conditions of flight crew $(n=1128)$ made available by the now defunct Ryanair Pilots' Group (RPG).

\section{4 | RENT-SEEKING IN A SINGLE MARKET}

Until recently, Ryanair deliberately avoided the most congested primary airports, not only because of slower turnaround and therefore lower utilisation of the airline's most costly assets (aircraft), but also to avoid strongholds of trade union organisation. As the company's annual rate of traffic growth slowed, the variation between summer (peak) and winter (low) passenger numbers increased, resulting in zero profit or even net losses during the winter season. Henceforth, the airline determined to fly to more primary airports and thereby compete for a larger pool of potential customers. This changing context-from secondary to primary airports-is an example of how rivalry restraint and commitment timing might dissipate over time when industrial relations enter 
the picture and (re)connect with strategic HRM. On the one hand, a firm with competitive advantage is hurt less by delaying commitment (opening routes to primary airports) because its relative strength makes rivals preemptive efforts less effective. As the former CEO of Vueling Airlines pointed out, 'We'll compete with anyone, but if Ryanair enters the route we wave the white flag' (Interview data). On the other hand, rather than surrender, the (re)action of other social actors might undermine the airline's competitive advantage. For example, when Ryanair started flights from Frankfurt and declared its intention to increase its share of the German market from $5 \%$ to $20 \%$, the German tax authorities launched an investigation into the 'self-employment' status of pilots based in Germany and Vereinigung Cockpit launched a new recruitment and organising campaign to secure union recognition for these pilots. In the field of industrial relations, stakeholders often fail to show restraint, especially when the timing is right.

Over time, more information has come to light on the terms and conditions of Ryanair's aircrew, creating an opportunity for aviation unions to organise around common grievances. If the SFM for labour is assumed to be perfectly competitive-as per the RBV-then, ipso facto, there must be perfect information. In the SEAM, however, information asymmetry (adverse selection) plays an important role in securing competitive advantage because many 'young Europeans who are desperate for work' (Interview data, ETF official) are unaware that they will be employed by an agency, rather than Ryanair, or that they will have to pay for their own training, at a cost of around $€ 5000$ to be repaid during the first 6 months of their 2-year, 0-h contract. These costs include a registration fee, accommodation, uniform hire, medical certificate, airport ID, criminal record check and an administration fee. Survey data reveal that, once hired, cabin crew working for Ryanair are more likely to rate their contracts of employment as 'unsatisfactory' (over 90\%) compared to aircrew at other LFAs such as easyJet (less than 10\%; Harvey \& Turnbull, 2014, p. 36). With a turnover rate (quits and dismissals) running at more than $30 \%$, it seems that the airline is able to 'fool many people at key points in time' (i.e., when hiring from the SFM for labour).

Pilots, in contrast, are well aware of the costs they face when seeking work with Ryanair-they will have already paid around $€ 100,000$ to obtain a commercial pilots licence and must now pay over $€ 29,000$ to Ryanair for their 'type-rate' training to fly a Boeing 737-800. As one pilot at a focus group remarked: 'Ryanair are in the business of selling airline seats and have found that they can make a lot of money selling the front right hand [First Officer/junior pilot] seat to young hopefuls' (FG data). For pilots, the information asymmetry is one of moral hazard: rates of pay have been progressively and substantially reduced, contrary to professional expectations, as Ryanair switched its primary supplier of pilot services, as illustrated in Table 1. Moreover, if pilots are promoted to captain, they will typically transfer to a different base and may then be paid less than other captains already flying from the assigned base. Pilots do not have 'free choice' over their base allocation, and like cabin crew can be transferred to any other base at the company's discretion without compensation. It is hardly surprising, therefore, that when the RPG asked its members $(n=1128)$ if they were satisfied with their current base more than $29 \%$ said 'no' and more than $36 \%$ had requested a base transfer. As a pilot explained on www.pprune.org, 'If you're a married guy with kids commuting home on your days off and forever trying unsuccessfully to get a transfer to your [domestic] home base, it absolutely sucks'. The SFM for labour is not simply a source of labour supply but also a place of employment and a space of exploitation. Unsurprisingly, almost a third of respondents to the RPG survey said they were planning to leave the company within the next 12 months and a further $22 \%$ within the next 2 years.

Instead of paying a wage that includes transfer earnings, such that pilots are deterred from seeking employment elsewhere, Ryanair is able to appropriate traditional Ricardian rents by paying below the 'competitive wage' in its SFM for labour where it is effectively the 'sole buyer' (monopsonist) of qualified but inexperienced pilots. Most airlines will only hire pilots with 1000-1500 h flying time. Ryanair hires the services of pilots with just $200 \mathrm{~h}$ experience, thereby securing the services of heterogeneous resources that can be retained for at least 1-2 years before the pilot accumulates sufficient hours to transfer to a different airline. As one union official explained, 'Many recruits do their time [with Ryanair] and then go chasing the 'desert dollars' with the Middle East airlines to pay off their debts' (Interview data). Cabin crew who quit within the first 15 months must pay an 'administration fee' of $€ 200$ and pilots must give 3 months' notice or pay an in terrorem 'penalty' of $€ 5000{ }^{4}$ Thus, aircrew are 'bonded' to 
TABLE 1 Hourly flight pay of pilots contracted to Ryanair

$\begin{array}{llcccc} & & \text { Brookfield 2014 } & \text { McGinley 2015 } & \text { BlueSky 2016 } & \text { Pay-cut, 2014-2016 (\%) } \\ \text { First officer } & <500 \mathrm{~h} & € 60.00 & € 55.00 & € 45.00 & -25.0 \\ & 500<1500 \mathrm{~h} & € 75.00 & € 70.00 & € 58.50 & -22.0 \\ & >1500 \mathrm{~h} & € 83.00 & € 75.00 & € 63.00 & -24.1 \\ \text { Captain } & & € 145.00 & € 145.00 & € 125.50 & -13.4\end{array}$

Source: Ryanair Pilots' Group.

the firm as a consequence of both the financial costs of training and payments in the event of early departure or insufficient notice.

Training costs and other 'payments to work', such as uniform hire, are modern-day markers of the neo-villein (Harvey et al, 2017). However, the more important characteristics of these 'airborne neo-villeins' is the absence of a guaranteed wage and unpaid labour. All 'self-employed' pilots are hired on a 0-h contract that includes significant (but unpredictable) incentive payments (just over $30 \%$ of total remuneration) and 1 month unpaid leave during the low winter season between November and March. Likewise, cabin crew are hired on a 0-h contract, around $40 \%$ of their compensation is variable, and they are required to take 3 months unpaid leave (compulsory furlough) in the low winter season. Unpaid work includes all time worked outside paid 'block hours' (i.e., the scheduled time between 'push back' for take-off to 'parking brakes on' after landing), which for cabin crew includes cleaning the aircraft in between flights during the target turnaround time of around 25-30 min. Pilots are paid for block hours as an addition to their basic (sector) pay, but still work additional time in two important respects. First, the 'per scheduled block hour' in the pilot's contract is often less than the actual time it takes to complete the flight. ${ }^{5}$ Secondly, although sector pay includes 45 min pre-flight checks reporting time, it often takes longer to complete this work depending on the experience of the crew, access to computers and printers, congestion at the airport, weather conditions and so on. Pilots often report early as failure to complete pre-flight checks on time (delayed departure) is regarded as a disciplinary offence and any such 'misdemeanours' count against a pilot who is keen to work tomorrow or who might apply for a base transfer at some time in the near future.

In a SEAM with 28 different labour markets, 'choice of law' is a strategic factor and the foundation of competitive advantage derived from the interaction of monopsony and neo-villeiny, enabling the airline to generate and appropriate traditional and non-traditional Ricardian rents. More than $90 \%$ of Ryanair's workforce is non-Irish. Nonetheless, as the airline is registered in Ireland the 'place of work' (the aircraft) is Irish sovereign territory and all contracts clearly state that the employment relationship is 'at all times governed by the laws in effect and as amended from time to time in the Republic of Ireland'. Legal interpretation, however, like other forms of social interaction, is contested, and contractual statements (boilerplate) are not necessarily contractual terms. To be sure, European law (Art.8(1) Rome I) allows the contracting parties to freely determine the applicable law for their contract, but the parties' choice of law may not have the result of depriving the employee of the protection of the regulatory elements of the objective labour statute. To determine the objective labour statute, a comparison of 'favourableness' must be carried out between the mandatory provisions of the objectively applicable law that affords the employee protection and those of the chosen legal system (European Court of Justice [ECJ] 15 March 2011, C-29/10). In several transport judgements, the ECJ has determined applicable law on the basis of the place 'from which' and not simply 'in which' the worker performs her or his duties (e.g., C-29/10 and $\mathrm{C}-384 / 10)$. The relevant social security legislation, as opposed to income tax payments, is now determined by the place where the person is physically located and with which she/he has a close connection in terms of employment. $^{6}$

Applicable law and the (un)favourableness of contractual terms are something for the courts to determine on a case-by-case basis in the light of all relevant circumstances. Understandably, aircrew are unwilling to embark on a 
prolonged legal challenge of their terms and conditions, certainly not without the support of a trade union. Member States have sought to impose new national laws on the 'home base', as in France (Décret no. 2006-1425), but whereas easyJet then switched to 'country of location' contracts, Ryanair abandoned its base (in Marseille). Likewise, when faced with the prospect of union recognition and a collective bargaining agreement as a result of industrial action and court cases in Denmark and Norway, Ryanair again closed the bases (Copenhagen and Rygge). This a clear example of HR strategy driving, or in this instance diverting, the business strategy, rather than the reverse.

Irish (common) law offers workers much weaker employment protection than other European (civil law) systems (OECD, 2013). Most notably, with no comprehensive statutory definition of either an 'employee' or 'contract of employment' the parties must refer to a Code of Practice (first published in 2001) to determine employment status. According to this Code, self-employment is characterised by, inter alia, ownership of one's business, responsibility for investment and management of the enterprise and the ability to cost and agree a rate for the job. ${ }^{7}$ Prior to 2009, Brookfield International (a UK-based agency) recruited pilots who were registered as 'self-employed' in Ireland and contracted directly to work exclusively for Ryanair. This set-up ran contrary to a decision of the Irish Competition Authority (No. E/04/002, 31 August 2004) and the Code of Practice, which clearly states that the selfemployed 'can provide the same services to more than one person or business at the same time'. After the Irish pilots' union sought clarification of the 'self-employment' status of Ryanair pilots in 2008, the Irish Revenue Commissioners declared that their 'self-employment' status would not be regarded as a 'contract for services'. In response, Brookfield immediately required all contract pilots to set up a 'pilot employment service provider' with several other pilots (typically unknown to each other) in any of one of the EU Member States or Switzerland to supply pilot services, via Brookfield, to Ryanair. The result was a significant increase in 'self-employed' pilots, from $56 \%$ to over $70 \%$. Here again, strategic changes to HRM can only be understood when (re)connected to industrial relations and SFMs.

'Self-employed' pilots pay taxes in the country where they register their business, not where they work. Most retain Irish registration because they are directed by Brookfield to Irish accountants to set up their 'selfemployment' business. More importantly, Ireland has much lower labour taxes compared to other EU Member States. 'Self-employment' certainly saves the employer of pilot services (Ryanair) a considerable sum. Based on the (mean) average salary reported by RPG members $(n=1128)$ and the total number of 'self-employed' pilots, the 'saving' (rent-seeking) compared to direct employment amounts to more than $€ 15$ million per annum. This is indicative of how monopsony power in the SFM for labour enables the airline to then appropriate rent via neovilleiny. Following an investigation of 'self-employed' pilots by the German tax authorities, Ryanair switched from Brookfield to BlueSky Resources (an Irish-registered company), which offers pilots a 5-year contract of employment, albeit at lower rates of pay (see Table 1).

When Michael O'Leary (Ryanair's CEO) was asked what appeals about 'self-employment' contracts, he commented: 'first that it makes it impossible for the pilot unions to have any influence over the Ryanair contract pilots, and second, that it gives Ryanair far more workforce flexibility than a settled, unionised labour force would ever allow in practice' (quoted by Learmont, 2013, p. 55). Put differently, the contractual status of aircrew differentiates these workers from the (permanent) staff of rival airlines (i.e., a heterogeneous resource that generates traditional Ricardian rents for Ryanair). Consequently, the ultra-low-cost airline has a degree of flexibility and (cost) control that is simply unattainable by other airlines (i.e., social dumping that generates non-traditional Ricardian rents). Under Irish law, the employer can establish an 'excepted body' for the purpose of collective bargaining, defined as: 'a body all the members of which are employed by the same employer and which carries on negotiations for the fixing of wages or other conditions of employment of its own members (but no other employees)' (Trade Union Acts of 1941, s.6(3)(h) and 1942, s.2, emphasis added). Pay and conditions for all flight crew are determined by base agreements 'negotiated' by Ryanair's own excepted bodies-base-specific Employee Representative Committees (ERCs)-even though sub-contract aircrew are excluded from the ERCs. Thus, 'deterritorialization of sovereignty is a way for capital to escape working class associational power, while still reaping the benefits of 
national class compromise' (Lillie, 2010, p. 687). Or as one union official put it: 'Ryanair plays multinational law when it suits them [the right to provide services in a SEAM] and Irish law when it doesn't' [i.e., whenever EU social law might trump Irish employment law] (Interview data).

Excepted bodies are not accepted by pilots and have been challenged in the courts. Initially, the Irish Supreme Court supported Ryanair's right 'not to deal with trade unions' and even asserted that: 'nor can a law be passed compelling it to do so' (Geoghegan J, Ryanair v. Labour Court [2007] 4 IR 199). However, as Kaufman 2015, p. 533 pointed out, if SFMs and RINO are used for rent capture, 'then, labour unions, labour law and HRM's social legitimacy enter the picture'. A law has now been passed in Ireland (Industrial Relations [Amendment] Act 2015) that defines the term 'collective bargaining', with particular reference to non-union companies. Said law restricts the circumstances under which an employee forum or works council can be considered an 'excepted body', thereby making it more difficult for an employer such as Ryanair to defeat an appeal to the Labour Court for union recognition on jurisdictional grounds.

More importantly, when the Irish Aviation Authority finally brought Irish flight time limitations into line with the rest of Europe (from January 2018), Ryanair flight crew were then required to take their annual month of unpaid leave before the end of December 2017 instead of the financial year running to the end of March 2018. This precipitated a pilot shortage. Even a cash bonus to entice pilots to work additional shifts failed to avert significant flight cancellations. This proved to be the political opportunity trade unions needed to organise strikes and secure recognition in several member states, bolstered by a ruling from the Court of Justice of the EU (Joined Cases C168/16 and C-169/16 Sandra Nogueira and Others v. Crewlink Ltd and Miguel José Moreno Osacar v. Ryanair). This ruling put paid to the 'convenient fantasy that aircraft registered in Ireland are somehow an airline's own "private kingdom" ... This argument has been wrongly used to deny mobile workers all over Europe their fundamental rights and made them feel like subjects, not employees' (Jon Horne, ECA Vice-President). ${ }^{8}$ Michael O'Leary protested that: 'This won't change Ryanair's cost base by one cent'. ${ }^{9}$ In contrast, the company's filing (FORM 20-F) to the US Securities and Exchange Commission more realistically noted that there 'may be a push for legacy type working conditions' (rent-sharing) which, if acceded to, 'could decrease the productivity of pilots, increase costs and have an adverse effect on profitability'. ${ }^{10}$ Ryanair's staff costs increased by over a third in the months that followed trade union recognition. In 2019, for the first time, Ryanair reported a substantial loss on its busy summer schedule.

\section{5 | CONCLUSIONS}

Ryanair's competitive advantage is rooted in its SFMs for labour and the law, which then 'permits' a particular configuration of HRM (neo-villeiny) that reinforces the airline's product market position and labour market power. That said, it remains to be seen whether Ryanair can sustain such a high profit margin. Rent-seeking begets opposition, opposition begets applicable law and union organisation, and union organisation begets the demand for higher basic pay, sick pay, a universal pension scheme, stable rosters, predictable working hours, compensation for disruptive schedules and more besides. Ryanair has flown itself into the turbulence of industrial action by aircrew across Europe, which reminds us that: 'they that sow the wind, shall reap the whirlwind'. Having exploited the limits of rent-seeking in the regulatory 'spaces of exception' in an open market and permissive industrial relations context, Ryanair now finds itself in a contested context of rent-sharing.

The generation of economic rents, and their distribution between capital and labour, is evidently determined in the external as well as the internal labour market. Put differently, SFMs and RINO are inseparable components of the RBV-it is not possible to apply one without the other. Over time, studies of HRM $\rightarrow$ performance have come to focus almost exclusively on competitive advantage derived from RINO. To be sure, if SFMs are assumed to be perfectly competitive, then RINO will take centre stage. In practice, however, SFMs are imperfectly competitive, especially the market for labour. SFMs not only offer the potential to generate traditional Ricardian rents but also activate non-traditional Ricardian rents. As demonstrated, whether or not a particular (universal) profit-generating 
mechanism will produce a high(er) return on capital will clearly depend on the industrial relations context in question and relationships between social actors. This speaks to repeated calls for (strategic) HRM to situate studies of HRM $\rightarrow$ performance in their socio-economic and political context and in particular to reconnect with industrial relations and other cognate disciplines in the social sciences. By focussing our attention on SFMs, on (buyer) power in the labour market, and on the appropriation as well as the generation of economic rent, the sociopolitical context of HRM in general, and industrial relations in particular, can explain how, when, where and why particular firms are able to sustain a competitive advantage.

\section{ACKNOWLEDGEMENT}

We gratefully acknowledge the financial support of the European Commission. We also thank Paul and Edwards and Andrew Sturdy, two editors and the referees for their comments on previous iterations of this paper.

\section{CONFLICT OF INTEREST}

We have no conflicts of interest to disclose.

\section{ORCID}

Geraint Harvey (D) https://orcid.org/0000-0001-8442-7527

\section{ENDNOTES}

${ }^{1}$ https://www.europarl.europa.eu/doceo/document/A-8-2016-0255_EN.html

2 https://www.youtube.com/watch? $v=$ mKDyeN2CYsE\&list=PL6sDcSCS8qsVT7dlpaEg4nW8Zyza3_34r\&t=0s\&index =5

${ }^{3}$ http://www.cabincrew.com/forums/ryanairs-cabin-crew-recruiter-stjames-management/221516/1; http://ryanairdont carecrew.blogspot.com/2014/03/ryanair-exploit-apprenticeshipcabin.html and https://www.aviationjobsearch.com/job/ ryanair-cabin-crew-training-recruitment-12/2019264

4 Mayors \& City of London Court, Case No. 1IR65128, 26 July 2013, Brookfield International Ltd v. Robertus Johannes Willhelmus Van Boekel.

${ }^{5}$ A review of scheduled versus actual flight times by the RPG revealed that around $20 \%$ of Ryanair's flights had less time formally allocated than the actual time it took to complete the flight.

${ }^{6}$ Under Regulation (465/2012/EC), agreed by a qualified majority in the Council of Ministers (only Ireland abstained), the pilot's 'home base' is defined as the place where the employee normally starts or ends his or her periods of duty and where, under normal conditions, the operator is not responsible for the accommodation of the aircrew in question.

7 https://www.revenue.ie/en/self-assessment-and-self-employment/documents/code-of-practice-on-employmentstatus.pdf

${ }^{8}$ https://www.eurocockpit.be/sites/default/files/2017-09/Press\%20Release\%20ECJ\%20Ruling\%20Ryanair\%20 Crewlink_1.pdf

9 https://uk.reuters.com/article/uk-ryanair-crew-court/ryanair-loses-eu-court-battle-to-keep-irish-law-for-crew-abroadidUKKCN1BPOV6

10 https://investor.ryanair.com/wp-content/uploads/2018/07/Ryanair-FY-2018-20F.pdf

\section{REFERENCES}

Alamdari, F., \& Fagan, S. (2005). Impact of the adherence to the original low-cost model on the profitability of low-cost airlines. Transport Reviews, 25(3), 377-392.

Allen, M., \& Wright, P. (2007). Strategic management and HRM. In P. Boxall, J. Purcell, \& P. Wright (Eds.), The Oxford handbook of human resource management, Oxford, England: OUP.

Barney, J. B. (1986). Strategic factor markets: Expectations, luck, and business strategy. Management Science, 32(10), 1231-1241.

Barney, J. B., \& Clark, D. N. (2007). Resource-based theory: Creating and sustaining competitive advantage. Oxford, England: OUP.

Barney, J. B., \& Mackey, A. (2016). Text and metatext in the resource-based view. Human Resource Management Journal, 26(4), 369-378.

Beer, M., Boselie, P., \& Brewster, C. (2015). Back to the future: Implications for the field of HRM of the multi-stakeholder perspective proposed 30 years ago. Human Resource Management, 54(3), 427-438.

Button, K. (2012). Low-cost airlines: A failed business model? Transportation Journal, 51(2), 197-219. 
Chadwick, C., \& Dabu, A. (2009). Human resources, human resource management, and the competitive advantage of firms: Toward a more comprehensive model of causal linkages. Organization Science, 20(1), 253-272.

Cooke, F. L. (2018). Concepts, contexts and mindsets: Putting human resource management research in perspective. Human Resource Management Journal, 28(1), 1-13.

Crane, A. (2013). Modern slavery as a management practice: Exploring the conditions and capabilities for human exploitation. Academy of Management Review, 38(1), 49-69.

EC. (2017). European pillar of social rights. Brussels, Belgium: European Commission.

Harvey, G., Rhodes, C., Vachhani, S. J., \& Williams, K. (2017). Neo-villeiny and the service sector: The case of hyper flexible and precarious work in fitness centres. Work, Employment and Society, 31(1), 19-35.

Harvey, G., \& Turnbull, P. (2012). The development of the low cost model in the European civil aviation industry. Brussels, Belgium: ETF.

Harvey, G., \& Turnbull, P. (2014). Evolution of the labour market in the airline industry due to the development of the low fares airlines (LFAs). Brussels, Belgium: ETF.

Harvey, G., \& Turnbull, P. (2015). Can labor arrest the 'sky pirates'? International trade unionism in the European civil aviation industry. Labor History, 56(3), 308-326.

Johns, G. (2017). Reflections on the 2016 decade award: Incorporating context in organizational research. Academy of Management Review, 42(4), 577-595.

Jorens, Y., Gillis, D., Valcke, L., \& De Coninck, J. (2015). Atypical forms of employment in the aviation sector. Brussels, Belgium: ECA. Retrieved from https://www.eurocockpit.be/sites/default/files/report_atypical_employment_in_aviation_15_0212_f.pdf

Kaufman, B. E. (2010). The theoretical foundations of industrial relations and its implications for labor economics and human resource management. Industrial \& Labor Relations Review, 64(1), 74-108.

Kaufman, B. E. (2015). Market competition, HRM, and firm performance: The conventional paradigm critiqued and reformulated. Human Resource Management Review, 25(1), 107-125.

Kaufman, B. E. (2015). The RBV theory foundation of strategic HRM: Critical flaws, problems for research and practice, and an alternative economics paradigm. Human Resource Management Journal, 25(4), 516-540.

Kilduff, P. (2010). Plane speaking: The wit and wisdom of Michael O'Leary. London, England: Aurum Press.

Langley, A. (1999). Strategies for theorizing from process data. Academy of Management Review, 24(4), 691-710.

Learmont, D. (2013). Pilot schemes. Airline Business, 29(5), 54-57.

Lillie, N. (2010). Bringing the offshore ashore: Transnational production, industrial relations and the reconfiguration of sovereignty. International Studies Quarterly, 54(3), 683-704.

Makadok, R. (2011). The four theories of profit and their joint effects. Journal of Management, 37(5), $1316-1334$.

Malighetti, P., Paleari, S., \& Redondi, R. (2016). Base abandonments by low cost carriers. Journal of Air Transport Management, 55, 234-244.

OECD. (2013). OECD employment outlook 2013. Paris, France: OECD Publishing.

O'Sullivan, M., \& Gunnigle, P. (2009). 'Bearing all the hallmarks of oppression': Union avoidance in Europe's largest low-cost airline. Labor Studies Journal, 34(2), 252-270.

Ricardo, D. (1817). On the principles of political economy and taxation. London, England: John Murray.

Ricardo-AEA. (2019). Study on employment and working conditions of aircrews in the EU internal aviation market (European Commission DG MOVE/E1/2017-556). Retrieved from https://www.sitcpla.es/images/Normativa/Study-on-employment-and-working-conditions-aircrews-020419.pdf

Tarry, C. (2010). Low-cost commodity. Airline Business, 26(2), 28-30.

Vincent, S., \& Wapshott, R. (2014). Critical realism and the organizational case study: A guide to discovering institutional mechanisms. In P. K. Edwards, J. O'Mahoney, \& S. Vincent (Eds.), Studying Organizations using critical realism (pp. 148-167). Oxford, England: OUP.

How to cite this article: Harvey G, Turnbull P. Ricardo flies Ryanair: Strategic human resource management and competitive advantage in a Single European Aviation Market. Hum Resour Manag J. 2020;1-13. https:// doi.org/10.1111/1748-8583.12315 